SVU- International Journal of Veterinary Sciences, 4 (3): 12-23, 2021.

\title{
Potential of Hydroponic Barley in Rabbit Diets: Effect on Productive Performance, Nutrient Digestibility, Microbiological and Physiological Responses
}

\section{Esraa M.H. Mohamed ${ }^{1}$, Hamdy A. Hassan ${ }^{1}$, Ahmed A.A. Abdel-Wareth ${ }^{1 *}$}

${ }^{1}$ Department of Animal and Poultry Production, Faculty of Agriculture, South Valley University, Qena 83523, Egypt.

\section{Abstract}

Application of agriculture hydroponic technology with a view to reduce the gap between the animal nutritional requirements and availability of feed ingredients create an important role in animal and rabbit production. Hydroponic fodder production such as barley is an alternative technology to cultivate fodder which provide the growing nutrients requirement for livestock feed with suitable prices, high quantity, a short growth period, a small land for production, a clean environment, water efficiently and reduces cultivate fodder resources. This study was investigated with view to give an overview on the possible role of hydroponic barley (HB) as a feed replacement in rabbit ration. Various scientific published research articles were used HB as a feed replacement in rabbit ration. The most observed and analyzed productive and reproductive performance, nutrient digestibility and physiological responses. Positive effect of feeding HB was observed on serum metabolic profile and microbial count of caecum of rabbits. However, the economics and nutritive values of hydroponic production system should be carefully estimated. This review provides an overview of and illustrates the positive effects of $\mathrm{HB}$ as a feed replacement in rabbit diets and their potential effects on productive performance, economic return, nutrient digestibility, microbiology and gut health of growing rabbits.

Keywords:

Hydroponic barley, Microbiology, Nutrition, Physiology, Rabbits.

DOI: $10.21608 / \mathrm{svu} .2021 .67695 .1114$

Published: August 10, 2021

E-mail: a.wareth@agr.svu.edu.eg

Citation: Mohamed et al., Potential of Hydroponic Barley in Rabbit Diets: Effect on Productive Performance, Nutrient Digestibility, Microbiological and Physiological Responses. SVU-IJVS 2021, 4 (3): 12-23.

Copyright: (C) Mohamed et al. This is an open access article distributed under the terms of the creative common attribution license, which permits unrestricted use, distribution and reproduction in any medium provided the original author and source are created.

Competing interest: The authors have declared that no competing interest exists. 


\section{Introduction}

Since feed costs accounts more than $70 \%$ of total production cost, it is very important to feed the animals according to their nutrient requirements for potential production, economic growth and sustainability (Gupta, 2014). Hydroponic is now emerging as an alternative technology to grow fodder for the animal farm due to the limitations in the conventional method of cultivated green fodder in most of the Middle East and African countries, (Sneath and Mclntosh 2003; Naik et al., 2011; Naik et al., 2012; and 2013). Therefore, fodder is produced without using any soil but growing the plants in water or mineral nutrient solution is known as hydroponics fodder or fresh fodder or sprouted grains (Dung et al., 2010; Bakshi et al., 2017). Furthermore, the increase of human requirements on land for producing cereal grains have made traditional green fodder cultivation hard to be augmented, beside other constrains such as climate change, water deficiency or water salinity, growth period, fertilizer requisite and expenses, (MOA, 2014; Gebremedhin et al., 2015; Saidi and Abo Omar, 2015; Hassanien et al., 2020; Gabr et al., 2020; Abdelsatar et al., 2021; Ali et al., 2021; Abdel-Lattief et al., 2020; Hassan et al., 2021; Farrag and Bakr, 2021).

Hydroponics is an alternative technology to cultivate fodder (Naik et al., 2011; Naik et al., 2012; and Naik et al., 2013). This technique can provide growing nutrients requirement for animal feed with suitable prices, and assurance of a continuous green forage production of high quantity over the year. Hydroponic barley (HB) production is a high technique of growing barley in a clean environment without chemicals and artificial fertilizer (Jensen and Malter, 1995). The HB production is alternative technology to cultivate fodder which provides the growing nutrients requirement for animal feed with suitable prices, high quantity, short growth period, small land for production, clean soil, safe water and reduces cultivate fodder resources (Mooney, 2005). Furthermore, the biological and economic performance of HB production and utilization depends on the agriculture conditions, dray matter (DM) content and water consumption (Fazaeli et al., 2012; Kide et al., 2015).

It is known that the contents of energy and protein in the diets of growing rabbits affect their growth rate. Energy and protein are the greatest significant factors essential to get maximum weight gain (Lebas, 1989). The rabbits' diets should contain about 10.5 MJ digestible energy (DE) $/ \mathrm{kg} \mathrm{DM}$ and diets offered ad libitum with at least 9.5 $\mathrm{MJ} / \mathrm{kg}$ DM DE improved growth performance (Santom et al., 1989). Feeding rabbits on diets containing low levels of fiber reduce growth performance of rabbits (De Blas et al., 1986). The HB contains about $15-18 \%$ crude protein and 8-10 $\mathrm{MJ} / \mathrm{kg}$ DM DE which considered good nutritional value for rabbit nutrition. The use of $\mathrm{HB}$ in feeding growing male or female rabbits showed significant nutritional benefits (Abouelezz and Hussien, 2017) mainly due to it nutritional values. Partial substitution of corn grains with $20 \%$ barely grains in rabbit diets increase body weight, feed intake and feed conversion ratio (El-Adawy et al., 2012). Replacing of $\mathrm{HB}$ at 20 or $40 \%$ of commercial feed in growing rabbit diets has favorable effects, however, higher level at $60 \%$ of $\mathrm{HB}$ in rabbit diets is not recommended because it negatively affects nutrients digestibility and feeding values of tested diets (Mehrez et al., 2018).

There are gradual decreases in DM and Nitrogen free extract (NFE) content, and increases in Ash, ether extract (EE), crude protein $(\mathrm{CP})$ and crude fiber $(\mathrm{CF})$ content by increasing age of HB sprouting (Mehrez et al., 2018). On the other hand, some researchers have indicated that replacing pelleted commercial feed by $\mathrm{HB}$ has negative effects on growth performance (Morales et al., 2009; Shanti et al., 2017; 
Gabr et al. 2020). Feed intake and growth rate decreased linearly by $\mathrm{HB}$ increase (Morales et al., 2009; Shanti et al., 2017). Also, both CP and DE intake decreased linearly (Shanti et al., 2017). Growing rabbits fed concentrate feed mixture showed the highest significant values of average total and daily gain, relative growth rate, performance compared with those fed HB diets (Gabr et al. 2020).

Concerning, carcass yield was not affected by replacing pelleted commercial feed by HB (Morales et al., 2009; Shanti et al., 2017; Gabr et al. 2020). Positive significant effect of feeding HB at levels of 20 and $40 \%$ is shown on concentrations of blood total protein, albumin and glucose (Mehrez et al., 2018). Rabbits fed HB diets significantly increased the total viable count of bacteria in caecum (Mehrez et al., 2018). Hydroponic barley could be used up to $30 \%$ in diets of growing rabbits.

Previous studies showed varying results in this aspect, which could be due to growth period, environmental conditions, and cultivated grains. The knowledge gaps from the past studies are considered, and the use of HB in rabbit ration is suggested. The findings have motivated further study on $\mathrm{HB}$ to find out the most methods and their optimal doses in rabbit rations. Finally, this review provides an overview of and illustrates the positive effects of $\mathrm{HB}$ as a feed replacement in rabbit diets and their potential effects on productive performance, economic return, nutrient digestibility, microbiology and gut health.

\section{Chemical composition and nutritional value of $\mathbf{H B}$}

Evaluation of nutritive value of $\mathrm{HB}$ (Fig. 1) is important aspect for the sustainability of products and productivity in rabbit production. Mehrez et al. (2018) reported that the barley seed form contains 93.1\% DM, 97.6 \% OM, $12.7 \%$ CP, 6.3\% $\mathrm{CF}, 1.8 \% \mathrm{EE}, 33.1 \%$ Neutral detergent fiber (NDF), $15.2 \%$ acid detergent fiber (ADF) and $2.4 \%$ ash. On the other hand, Gebremedhin et al. (2015) found that the barley seed form contains $93.81 \% \mathrm{DM}$, $11.11 \% \mathrm{CP}, 8.9 \% \mathrm{CF}, 1.68 \% \mathrm{EE}, 20.1 \%$ NDF, $1.81 \%$ total ash, and $8.0 \%$ ADF. Furthermore, Kide and Abrha (2016) reported that 6 days-HB contains $11.11 \%$ $\mathrm{CP}, 3.35 \% \mathrm{EE}, 8.9 \% \mathrm{CF}, 57.5 \% \mathrm{NDF}$ and $38.36 \%$ ADF.

Sprouting of cereal grains produced an increased nutrient quantity and quality such as protein, digestible energy, fats, sugars, minerals and vitamin contents (Cuddeford, 1989; Gebremedhin, 2015). Based on previous studies, the chemical structure of $\mathrm{HB}$ as DM, OM, CP, CF, EE, GE, NDF, ADF, ADL, contents were suitable to replacement the concentrate feed in rabbit. For example, HB contained suitable amount of DM, OM, CP, NDF, ADF and DE, which improve growth performance of rabbits (Shanti et al. 2017). Likewise, Abouelezz et al. (2019) indicated that HB contains $23.3 \%$ CP, $4.17 \%$ EE, $26.7 \%$ NFE, and $3.97 \%$ ash as DM basis. Moreover, the chemical compositions could be affected by the cultivation conditions in hydroponic systems. The increase in EE content could be due to the production of chlorophyll associated with plant growths that are recovered in ether extract measurement (Mayer and Poljakoff-Mayber, 1975). The higher content of $\mathrm{CF}$ in $\mathrm{HB}$ may be due to the synthesis of structural of NDF, ADF, ADL (Cuddeford, 1989).

The lower value of DM in HB may be related to that the increase of water initiates increases metabolic activity of resting seeds leading to loss of dry weight through the germination of HB (Morsy et al., 2013; Abd-El-Khalek, 2020). Such changes in nutrients profile and recovery are misleading, since they only described the alterations in the proportion of nutrients during growth and sprouting of seeds (Morgan et al. 1992). A change in the weight of either the nutrient led to proportional changes in other compositions. 
Digestible crude protein has values from 11.26 to $11.36 \%$ while digestible energy has values from 2822 to 2945 $\mathrm{kcal} / \mathrm{kg}$ diet (Mohsen et al., 2015). Mehrez et al. (2018) found that 7-day HB contains $15.0 \%$ DM, $96.3 \%$ OM, $16.0 \%$ CP, $14.5 \%$ $\mathrm{CF}, 3.1 \% \mathrm{EE}, 38.5 \% \mathrm{NDF}, 3.7 \%$ ash, and $22.7 \%$ ADF. Also, Nagadi (2019) reported that 8 days HB contains $17.5 \%$ DM, $91 \%$ OM, $15.2 \% \mathrm{CP}, 15.9 \% \mathrm{CF}, 4.0 \% \mathrm{EE}, 3.9$ $\%$ ash, 39.4\% NDF, $61 \%$ NFE, 3171.2 (Kcal/kg DM) DE and 4424.3 (Kcal $/ \mathrm{kg}$ $\mathrm{DM})$ gross energy (GE). Furthermore, Kide and Abrha (2016) reported that the 8th-day grown $\mathrm{HB}$ contains $13.89 \% \mathrm{CP}, 3.60 \% \mathrm{EE}$, $14.2 \% \mathrm{CF}, 35.3 \% \mathrm{NDF}$ and $16.20 \% \mathrm{ADF}$ content. Moreover, Ata (2016) showed that the chemical composition of $\mathrm{HB}$ contains $15.3 \% \mathrm{DM}, 22.5 \% \mathrm{CP}, 11.4 \% \mathrm{CF}, 3.2 \%$ EE, $32.5 \% \mathrm{NDF}$ and $13.1 \%$ ADF. The fresh-8-day $\mathrm{HB}$ contains $13.64 \% \mathrm{DM}$, $13.89 \% \mathrm{CP}, 14.2 \% \mathrm{CF}, 3.6 \% \mathrm{EE}, 35.3 \%$ NDF, $4.1 \%$ total ash and $16.2 \%$ ADF. Also, fresh 7-day hydroponic barley fodder contains $14.2 \% \mathrm{DM}, 14.44 \% \mathrm{CP}, 5.67 \% \mathrm{EE}$ and $13.5 \% \mathrm{CF}, 64.66 \% \mathrm{NFE}, 3.4 \%$ total ash, $0.68 \%$ Calcium content and $0.46 \%$ Phosphorus content (Gebremedhin, 2015). The fresh-8-days HB contained $16.38 \%$ DM, $23.03 \%$ CP, $4.17 \%$ EE, $26.7 \%$ NDF and $3.97 \%$ ash (Abouelezz et al., 2019). Also, the fresh-8-day HB contained $17.30 \%$ $\mathrm{DM}, 15.75 \% \mathrm{CP}, 15.90 \% \mathrm{CF}, 4.05 \% \mathrm{EE}$, $60.96 \%$ Nitrogen free extract (NFE) and $3.34 \%$ ash (Abouelezz and Hussein, 2017).

Furthermore, the chemical composition of $\mathrm{HB}$ contents $18.65 \% \mathrm{DM}, 96.40 \% \mathrm{OM}$, $17.01 \% \mathrm{CP}, 12.73 \% \mathrm{CF}, 3.31 \% \mathrm{EE}, 3.60 \%$ ash (Mohsen et al., 2015). Also, Gabr et al., (2020) reported that the chemical composition of $\mathrm{HB}$ resulted in $15.0 \% \mathrm{DM}$, 96.3\% OM, $16.0 \% \mathrm{CP}, 14.5 \% \mathrm{CF}, 3.04 \%$ EE, $54.0 \%$ NFE and $3.70 \%$ ash. Shanti et al. (2017) found that the fresh-8-day HB contains $18.0 \% \mathrm{DM}, 2.0 \% \mathrm{CP}, 15.0 \% \mathrm{CF}$, $2.50 \%$ EE, $62.0 \%$ NFE and $5.0 \%$ ash. Morales et al., (2009) showed that the chemical composition of HB contains $16.10 \% \mathrm{DM}, 13.50 \% \mathrm{CP}, 16.30 \% \mathrm{CF}$, $2.55 \%$ EE, $62.9 \%$ NFE and $4.80 \%$ ash. Abd Rahim and Omar (2015) showed that the chemical composition of $\mathrm{HB}$ contains $18.3 \%$ DM, $19.8 \%$ CP, $10.4 \%$ CF, $35.40 \%$ NDF, $11.90 \%$ ADF, $3.20 \%$ calcium, 4.10 $\%$ phosphorus and $3.60 \%$ ash. The nutritive value variations of $\mathrm{HB}$ in the precious studies may be due to HB growth period, cultivated conditions and methods as well as the chemical methods.

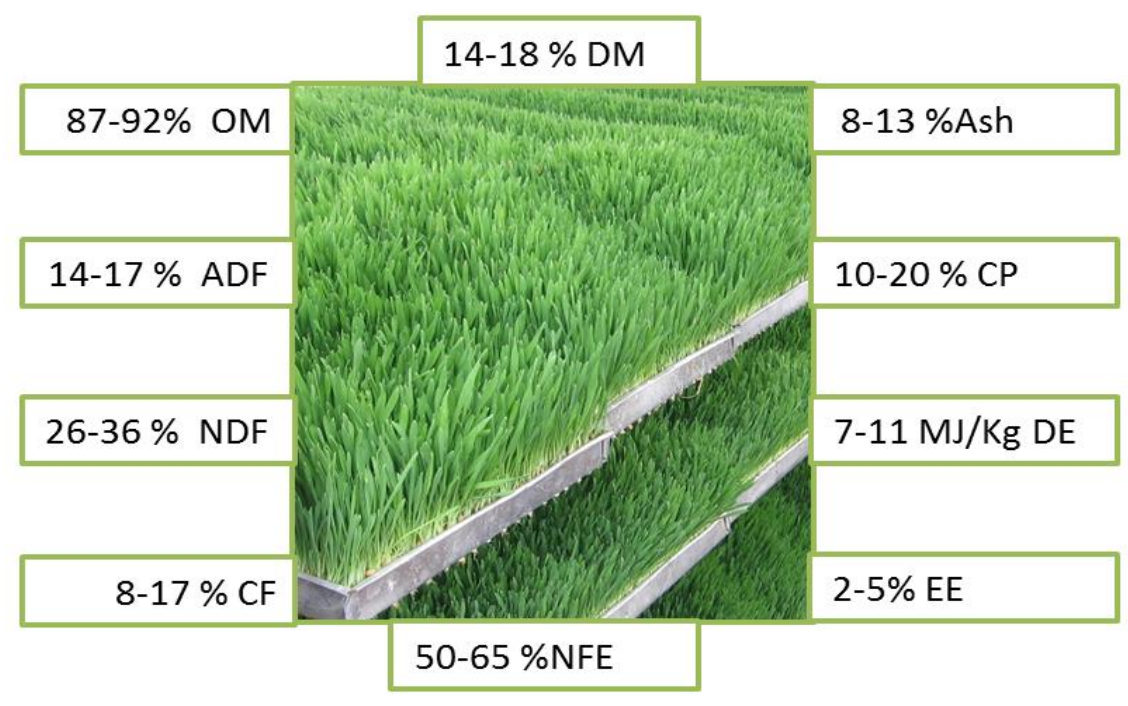

Chemical composition of hydroponic barley

Fig. 1. Approximate chemical composition of hydroponic barley 


\section{Influence of hydroponic barley on growth performance and feed cost of growing rabbits}

Recently, rabbit production has developed rapidly, most especially to cover the increasing demand in fresh meat for human consumption as well as extra income for farmers therefore much research was conducted to improve the productive performance and meet quality of rabbits (Abdel-Wareth et al., 2015; Abdel-Wareth et al., 2018; Abdel-Wareth et al., 2019; AbdelWareth and Metwally, 2020; Abdel-Wareth et al., 2020). Several feeding strategies have been developed during the last two decades for the utilization of safe and cheap feed for animals. Furthermore, various studies have been conducted to explore the use of $\mathrm{HB}$ on growth performance of rabbits. Abouelezz and Hussein (2017) carried out two experiments in order to conclude the nutrient composition and feeding value of the hydroponic barley fodder (HBF) and that HBF irrigated with bakers' yeast (HBFY) for the growing Californean and White New Zealandean rabbits. They showed that the male rabbits provided with $\mathrm{HBF}$ recorded the highest body weight, body weight gain and feed intake $(\mathrm{P}<0.05)$, while HBFY male rabbit had the worst $(\mathrm{P}<0.01)$ feed conversion ratio and for females, they found that the animals fed HBF and HBFY had lower $(\mathrm{P}<0.01)$ concentrate feed intake compared to control females (111.9 and 127.0 vs. $157.6 \mathrm{~g} / \mathrm{d}$ ) and HBF improved feed conversion ratio in HBF females compared to control group. The rabbits fed HB plus anaerobic probiotics addition are higher in final body weight, total body weight gain and daily body weight gain and feed conversion ratio than the other tested groups of rabbits (Nagadi, 2019).

The use of vegetated fenugreek seeds (SF) and/or barley grains (SB) on rice straw and their mixtures at different levels $(0,25$, 50,75 and $100 \%$, respectively) in growing New Zealand White rabbit's diet resulted in rabbits fed $28 \% \mathrm{SF}$ and $28 \% \mathrm{SB}$ diet have higher body weight gain than those fed control (clover hay) diet (Sekken et al., 2012). The effect of substitution of corn with different levels of barley grains $(0,5,10,15$, 20 and $25 \%$ ) of the total diet on growth performance of growing male New Zealand White rabbits resulted in rabbits fed the $20 \%$ barley grains diet have significantly $(\mathrm{P}<0.05)$ the highest live body weight value, while those fed the $25 \%$ barley grains diet have significantly $(\mathrm{P}<0.05)$ the highest feed intake value and the highest feed conversion ratio (FCR) is recorded for rabbits fed $20 \%$ $\mathrm{BG}$ diet and then those of $15 \% \mathrm{BG}$ and $25 \%$ BG diets (El-Adawy et al., 2012). Gabr et al., (2020) studied the effect of partial replacing of concentrate feed mixture (CFM) diet by $\mathrm{HB}$ on productive performance of growing APRI male rabbits resulted in rabbits fed control diet is significantly $(\mathrm{P}<0.05)$ higher in body weight gain, relative growth rate, and performance index, than those fed HB diets. Replacing pelleted commercial feed by $\mathrm{HB}$ for 32 days of age growing local Baladi rabbits resulted in dry matter feed intake and growth rate reduced linearly by $1.16 \pm 0.080 \mathrm{~g} / \mathrm{d}(\mathrm{P}<0.001)$ and $0.998 \pm 0.062$ $\mathrm{g} / \mathrm{d} \quad(\mathrm{P}<0.001)$ per unit of $\mathrm{HB}$ increase (Shanti et al., 2017).

Substituting HB offer a commercial feed of growing New Zealand rabbits from 35 to 70 day of age resulted in dry matter feed intake and growth rate decreased in substituting treatments, however, feed conversion was not influenced by treatments (Morales et al., 2009). Recently, it has been a major aim for Nutritional scientists to study the rabbit performance and minimize the feeding costs. Moreover, the most important factors involved in achievement of maximum meat production efficiency values depend on the body weight gain, the growing period length and the cost of feed. Application of $\mathrm{HB}$ as a substitution concentrate feed in growing rabbit diets improved economic return and reduced the total feed cost (Nagadi, 2019). Furthermore, Abouelezz and Hussein (2017) reported that substitution $\mathrm{HB}$ of commercial diet of 
fattening rabbits reduced feed cost per gain than the control. In economic point of view, HB has a short growth period between 7-10 days and requires a small piece of land area for production (Mooney, 2005). Also, HB improved body weight gain, feed conversion ratio and economic efficiency (Fayed, 2011).

\section{Influence of hydroponic barley on nutrient digestibility of growing rabbits}

Sprouting of cereal grains produced an increased nutrient quantity and quality such as protein, digestible energy, fats, sugars, minerals and vitamin contents (Cuddeford, 1989; Gebremedhin, 2015). Moreover, HB is rich in enzymes, therefore, feeding of the HB improves the digestibility and productive performance of animals due to removal the acidic conditions. As well as, sprouting grains are serving in the removal the anti-nutritional. The digestibility of $\mathrm{OM}$, TDN, CP and NFE in HB was higher than values of control diet (Sekken et al., 2012). Also, Nagadi (2019) studied the effects of feeding partial substitution of fresh 8 daysage HB with different levels $(0,25,50 \%)$ for concentrate fodder with or without probiotics on digestible coefficients of growing male New Zealand white rabbits and resulted in $\mathrm{DM}, \mathrm{CP}, \mathrm{CF}$ and $\mathrm{NFE}$ digestible coefficients for rabbits fed rabbits fed $\mathrm{HB}$ plus anaerobic probiotics addition are significantly higher $(\mathrm{p}<0.05)$ than other rabbit's groups. Also, all rabbits' groups have DM higher than those fed control diet. The TDN and DCP nutritive values are higher for rabbits fed $25 \% \mathrm{HB}$ diet and rabbits fed $\mathrm{HB}$ plus anaerobic probiotics addition diet than other groups.

On the other hand, Mehrez et al. (2018) showed that DM, OM, EE and NFE digestibility in rabbits fed commercial concentrate feed mixture are significantly $(\mathrm{P}$ $<0.05$ ) higher than those fed 20\%,40\% and $60 \%$ HB diets. Conversely, values of $\mathrm{CP}$ and CF digestibility for the group fed $20 \% \mathrm{HB}$ diet (78.62\% and $59.42 \%$, respectively) are significantly $(\mathrm{P}<0.05)$ higher than those fed
$40 \%$ HB diet and control diet. They also observed that the $\mathrm{CP}$ and $\mathrm{CF}$ values for the group fed $60 \%$ HB diet $(59.42 \%$ and 25.74 $\%$, respectively) are the lowest between the four diets. For the nutritive value of tested diets, but TDN and DE values for the groups fed control diet and $20 \%$ hydroponic barley diet (64.91 and $63.30 \%$, respectively) are significantly $(\mathrm{P}<0.05)$ higher than those fed $40 \%$ hydroponic barley diet (55. $22 \%)$ and $60 \%$ hydroponic barley diet (45.11\%). Also, Mohsen et al. (2015) showed that the digestibility coefficients of different nutrients and nutritive values are almost comparable for the commercial rabbit diet and the diets contained $30 \% \mathrm{HB}$.

Using $\mathrm{HB}$ could be increased the digestible of the nutrients which could be qualified to the tenderness of the fodder (Naik et al., 2013). These enhancements might be due to high content of leafy, roots sprouts which is easy to digest and hydrolysis by the enzymes of gut microflora, as well as enzymatic digestion such as proteases present in the lytic vacuoles of plant cells. In this connect, Chung et al. (1989) said that high soluble protein and amino acids refer to the response in the early plant growth and enzymatic changes of sprouted grains are responsible for improving the digestibility in the animals.

\section{Microbiological, Physiological and histological response of rabbits to hydroponic barley}

Related to microbiological response of rabbits to HB, also, rabbits fed HB diets (20, 40 and $60 \%)$ was significantly $(P<0.05)$ increased total viable count of bacteria in caecum and high percentage of diarrhoeal cases compared with those fed the control diet without HB (Mehrez et al., 2018). This may be related to the moisture content of HB diets and could be increased by pathogenic bacteria such as coliforms and especially $E$. coli which are important opportunist pathogens and can be a major cause of enteritis and losses in rabbit farm. The 
pathogenic and toxigenic bacteria cause diarrhea in rabbits (Harcourt-Brown, 2002). However, more studies are needed to clarify the fractions of population of bacteria (beneficial or pathogenic bacteria) in cecum of rabbits fed $\mathrm{HB}$ diets to implement the intestinal health of rabbits (Bivolarski et al. 2011). Also, Belenguer et al. (2000) indicated that concentration of total bacteria is higher $(\mathrm{P}<0.05)$ in barley grains diets than corn grains diets and high addition of barley grains augmented the total bacterial count in the cecum.

Replacing concentrate feed mixture with HB significantly increases the total viable bacterial count, since HB has shown much improving positive effects on growth performance and control of pathogenic bacteria (El-Gogary et al. (2018).

It is important to consider the specific effects of $\mathrm{HB}$ on physiological response of rabbits before used as feed. Furthermore, serum metabolic profiles are reflected on health status and are good indicators of rabbit physiological, pathological, and nutritional status. Nagadi (2019) studied the substitution of HB as a partial replacement for concentrate feed contains anaerobic probiotics and resulted in HB diet with or without addition of anaerobic probiotics have higher total protein, globulin, albumin total lipid and total cholesterol in serum blood than those fed control diet, but there are no significant differences between the groups on creatine, aspartate aminotransferase (AST) and alanine aminotransferase (ALT). Mehrez et al. (2018) reported positive significant $(\mathrm{P}<0.05)$ influence of substituting a commercial feed with $\mathrm{HB}$ at levels of 20 and $40 \%$ on total protein, albumin, AST and glucose, however, globulin, cholesterol, triglycerides, urea and creatine were not significantly differences among tested groups. They also, concluded that most plasma parameters values are within the normal ranges for rabbits given 5.4-7.3 g/dl total protein, 2.4-4.5 g/dl albumin, 2.9-4.9 $\mathrm{g} / \mathrm{dl}$ globulin, $80-150 \mathrm{mg} / \mathrm{dl}$ glucose, $10-80$ $\mathrm{mg} / \mathrm{dl}$ cholesterol, 10-45 IU/l ALT and 10120 IU/l AST. Shanti et al. (2017) studied the effect of substituting a commercial feed with HB on 32 days of age growing local Baladi rabbit blood biochemistry and showed that blood metabolites are within the MEDIRABBIT standards and are variably affected by the diets fed. Feeding HB had no effects on creatine, albumen, globulin and AST. Nevertheless, HB decreased levels of blood urea and total protein and has variable effects on other blood metabolites as cholesterol, triglycerides and ALT.

Unfortunately, there are no studies on impact of HB on development of gut and internal organs health of rabbits, therefore, more studies are needed to clarify the impact of $\mathrm{HB}$ on histological response of rabbits.

\section{Effects of $\mathrm{HB}$ on carcass criteria of rabbits}

The rabbits provided with fresh $\mathrm{HB}$ recorded the highest carcass weight, forelegs weight, and hind part than the values obtained in control and HB irrigated with bakers' yeast groups (Abouelezz and Hussein, 2017). Nagadi (2019) reported that empty carcass with head and dressing ratio was significantly improved by rabbits fed 50\% HB with anaerobic probiotics addition diet. The rabbits fed HB diet with addition of anaerobic probiotics have higher liver \%, kidney $\%$, and edible giblets percentage than those fed control diet. Nevertheless, all rabbits' groups show insignificant differences in heart percentage. Gabr et al. (2020) studied the effect of partial replacing of concentrate feed mixture diet by $\mathrm{HB}$ on carcass traits of growing male rabbits and reported that the dressing percentage, liver, lung and the relative weight of intestine are not significantly differ among rabbits fed control diet and those fed HB diets. However, the weight of hot carcass is significantly $(\mathrm{P}<0.05)$ influenced by inclusion of $\mathrm{HB}$ in the diet, where rabbits fed concentrate feed mixture are the heaviest (1132 g) then rabbits fed 40\% HB, 20\% HB, 
and $60 \% \mathrm{HB}$ diets $(870 \mathrm{~g}, 835 \mathrm{~g}$ and $727 \mathrm{~g}$, respectively). El-Adawy et al. (2012) studied the effect of substitution of corn with different levels of barley grains at $0,5,10$, 15,20 and $25 \%$ of the total diet on carcass characteristics of growing male New Zealand White rabbits and found that the per-slaughter weight, hot and cold carcass weight and dressing percentage are significantly $(\mathrm{P}<0.05)$ different in the tested groups and that the group of rabbits fed $20 \%$ barley grains diet has the highest value. They also showed that the relative weight of liver, heart, spleen, gallbladder, lungs plus trachea and full is not differ among the tested rabbit groups. Though, kidneys relative weight is significantly differed $(\mathrm{P}<0.05)$ among the tested rabbits' groups. Mohsen et al. (2015) reported that the slaughter and carcass weights and dressing percentage are not affected by $\mathrm{HB}$ addition in diets And indicated that the weights and percentages of organs are slightly influenced by HB enclosure in diets with the exception of liver percentage, spleen weight and the weight and percentage of shoulder fat shown significant differences $(\mathrm{P}<0.05)$. Morales et al., (2009) showed that dressing percentage of rabbits is not affected by replacing a commercial feed with hydroponic green barley forage. Also, Shanti et al. (2017)reported that inclusion of HB has variable effects on visceral organs of rabbits and the higher levels of HB addition (40 and $60 \%)$ produced a significant increase $(\mathrm{P}$ $<0.05$ ) in gall bladder and heart weights but other visceral organs are not affected by HB feeding. Mehrez et al. (2018) reported that the significantly $(\mathrm{P}<0.05)$ highest cecum length was recorded with rabbits fed 40 and $60 \% \mathrm{HB}$, while the significantly $(\mathrm{P}<0.05)$ lowest value was observed with group fed $20 \%$ HB. Similarly, Sekken et al. (2012) found that the length of rabbit caecum was significantly higher in HB diets than control.

\section{Conclusions and Future Perspective}

The findings of various scientific studies on hydroponic barley reveal that hydroponic barley represents an effective partial replacement for the commercial diets in rabbit nutrition. Their apparent actions include improved growth performance, nutrient digestibility, economic benefits of feed efficiency and serum metabolic profile as well as inhibition of pathogens.

\section{Conflict of interest statement}

The author declares that there are no conflicts of interest regarding publication of this article.

\section{References}

Abd Rahim, MA, Omar, JA (2015). The biological and economical feasibility of feeding barley green fodder to lactating awassi ewes. Open Journal of Animal Sciences, 5(2): 99.

Abd-El-Khalek, M (2020). Combined effect of vital wheat gluten, ascorbic acid and emulsifier addition on the quality characteristics of whole grain barley bread. SVU-International Journal of Agricultural Sciences, 2(2): 256-277. doi:10.21608/svuijas.2020.43026.1038

Abdel-Lattief, E, Ali, M, Ali, A (2020). Effect of nutrients management on yield attributes of fodder beet under sandy soil conditions. SVUInternational Journal of Agricultural Sciences, 2(2): 78-92. doi: 10.21608/svuijas.2020.36852.1018.

Abdelsatar, M, Elmasry, H, Attia, M (2021). Role of potassium fertilizer in improving yield and its components for some sesame varieties under saltaffected soil conditions. SVUInternational Journal of Agricultural Sciences, 3(1): 18-30. doi: 10.21608/svuijas.2021.57254.1067.

Abdel-Wareth AAA, Ahmed AE, Hassan HA, Abd El-Sadek MS, Ghazalah AA, Lohakare J (2019). Nutritional impact 
of nano-selenium, garlic oil, and their combination on growth and reproductive performance of male Californian rabbits. Anim Feed Sci Technol. 249(3): 37-45.

Abdel-Wareth AAA, Kehraus S, Ali AHH, Ismail ZSH (2015). Sudekum KH. Effects of temporary intensive feed restriction on performance, nutrient digestibility and carcass criteria of growing male Californian rabbits. Arch Anim Nutr. 69:69-78.

Abdel-Wareth AAA, Taha EMM, Sudekum KH, Lohakare J (2018). Thyme oil inclusion levels in a rabbit ration: Evaluation of productive performance, carcass criteria and meat quality under hot environmental conditions. Anim Nutr. 4(4):410-6.

Abdel-Wareth, AAA, Al-kahtani, MA, Alsyaad, KM, Metwally, AE, Ahmed, AE (2020). Combined supplementation of nano-zinc oxide and thyme oil improves the nutrient digestibility and reproductive fertility in the male californian rabbits. Animals, 10(12): 113.

Abdel-Wareth, AAA, Metwally, AE (2020). Productive and physiological response of male rabbits to dietary supplementation with thyme essential oil. Animals, 10(10): 1-11.

Abouelezz, FMK, Hussein AMA (2017). Evaluation of baker's yeast (saccharomyces cerevisiae) supplementation on the feeding value of hydroponic barley sprouts for growing rabbits. Egypt. Poult. Sci., 37: 833-854.

Abouelezz, FMK, Sayed, MAM, and Abdelnabi MA (2019). Evaluation of hydroponic barley sprouts as a feed supplement for laying Japanese quail:
Effects on egg production, egg quality, fertility, blood constituents, and internal organs. Animal Feed Science and Technology, 252: 126-135.

Ali, M, Abd El-Lattief, E, Khalaphallah, R, Mohamed, S (2021). Impact of levels of nitrogen fertilizer and types of irrigation water on yield and yield components of barley crop. SVUInternational Journal of Agricultural Sciences, 3(1): 72-84. doi: 10.21608/svuijas.2021.60182.1075.

Ata, M (2016). Effect of hydroponic barley fodder on awassi lambs performance. Journal of Biology, Agriculture and Healthcare, 6(8): 6064.

Bakshi, MPS, Wadhwa, M, Makkar HPS (2017). Hydroponic fodder production: A critical assessment. Broadening Broadening Horizons $\mathrm{N}^{\circ} 48$, December 2017.https://www.feedipedia.org/sites/ default/files/public/BH_048_hydropon ic_fodder.pdf.

Belenguer, A, Fondevila, M, Balcells, J, Torre, C (2000). Effect of the source and level of cereal in diet on the rabbit caecal environment and microbial population. $7^{\text {th }}$ World Rabbit Congr., Valence, Spain. World Rabbit Sci, 8: 95-100.

Bivolarski, B, Beev, G, Denev, S, Vachkova, E, Kostadinova, G, Slavov, T (2011). Development of the caecal microbiota in rabbits weaned at different age. Agricultural Science and Technology, 3 (3): 212-219.

Chung, TY, Nwokolo EN, Sim JS (1989) Compositional and digestibility changes in sprouted barley and canola seeds. Plant Foods for Human Nutrition 39:267-278. 1989. 
Cuddeford, D (1989). Hydroponic grass. In Pract. 11: 211-214.

De Blas, JC, Santoma G, Carabono R, Fraga, MJ (1986). Fiber and starch levels in fattening rabbit diets. J. Anim. Sci., 63: 1897-1904.

Dung, DD, Godwin, IR, Nolan, JV (2010). Nutrient content and in sacco degradation of hydroponic barley sprouts grown using nutrient solution or tap water. J. Anim. Vet. Adv., 9 (18): 2432-2436.

El-Adawy, MM, Mohsen, MK, Salem, AFZ, Mariezcurrena, BMA, El-Santiel, GS, Dakron, MZ (2012). Growth performance and carcass composition of rabbits fed on diets of gradual levels of barley grain. Tropical and subtropical agroecosystems, 15(2).

El-Gogary, MR, Mansour, AM, El-Said, EA (2018). Blood biochemical and immunological responses to garlic oil administration in growing rabbits' diet. Journal of Agricultural Science, 10(1): 217-224.

Farrag, H, Bakr, A (2021). Biological reclamation of a calcareous sandy soil with improving wheat growth using farmyard manure, acid producing bacteria and yeast. SVU-International Journal of Agricultural Sciences, 3(1): 53-71. doi: 10.21608/svuijas.2021.57919.1070.

Fayed, AM (2011). Comparative study and feed evaluation of sprouted barley grains on rice straw versus tamarix mannifera on performance of growing Barki lambs in Sinai. Journal of American Science, 7 (1):954-961.

Fazaeli, HHA, Golmohammadi, SN, Tabatabayee, MA (2012). Productivity and nutritive value of barley green fodder yield in hydroponic system. World Applied Sciences J., 16 (4): 531 539.

Gabr, AA, Mehrez, AZ, El-Ayek, MY, Gad, AM (2020). Effect of partial substitution of a commercial concentrate feed mixture crude protein by hydroponic barley fodder in diets of apri rabbits on: 2-growth performance, slaughter and carcass traits, meat composition and economic efficiency. Egyptian J. Anim. Prod. (57): 121-126.

Gebremedhin, WK (2015). Nutritional benefit and economic value of feeding hydroponically grown maize and barley fodder for Konkan Kanyal goats. IOSR J. Agric. Vet. Sci, 8: 2430.

Gebremedhin, WK, Deasi, BG, Mayekar, AJ (2015). Nutritional Evaluation of Hydroponically Grown Barley Fodder. seed, 93(6): 91.

Gupta, JJ (2014). Fodder production and livestockfeeding management in Eastern India (Unpub.), ICAR Research Complex for Eastern Region, Patna.

Harcourt-Brown, F (2002). Textbook of Rabbit Medicine, Butterworth, Heinemann, Oxford, UK.

Hassan, M, Raslan, M, Kalhy, G, Ali, MA (2021). Evaluation and path analysis for yield and its components in some genotypes of lentil (Lens culinaris Medikus) under Upper Egypt condition. SVU-International Journal of Agricultural Sciences, 3(2): 37-51. doi:10.21608/svuijas.2021.65161.1084

Hassanien, H, Baiomy, A, Hassan, H, Badry, $H$ (2019). The effect of dietary doum supplementation on productive and reproductive performance of male 
rabbits in Upper Egypt. SVU-

International Journal of Agricultural

Sciences, 1(1): 70-82. doi: 10.21608/svuijas.2019.67087.

Hussein MA, Ismail, ZSH Abdel-Wareth, AAA (2020). Application of zinc oxide nanoparticles on productive performance in rabbit nutrition: A Review. SVU-International Journal of Agricultural Sciences, 2 (2): 278-290.

Jensen, H, Malter A (1995). Protected agriculture a global review. World bank technical paper number $253.156 \mathrm{p}$

Kide, W, Abrha, R (2016). Yield and nutritive value of barley (hordium vulgari 1.) Fodder grown in soil and hydroponic system. Life Sciences International Research Journal, 3(2).

Kide, W, Desai, B, Kumar, S (2015). Nutritional improvement and economic value of hydroponically sprouted maize fodder. Life Sciences International Research Journal 2:76-79.

Lebas, F (1989). Besoins nuttritionnels des lapins. Cuni-Sciences, 5: 1-27.

Mayer, AM, Poljakoff-Mayber, A (1975). The Germination of Seeds, $\left(2^{\text {nd }} e d\right)$. Pergamon Press, Toronto.

Mehrez, AZ, Gabr, AA, El-Ayek, MY, Gad, AM (2018). Effect of Partial Substitution of a Commercial Feed Crude Protein by Hydroponic Barley Fodder in Diets of Apri rabbits on: 1Digestibility, Feeding Value, some Blood Constituents and Caecum Microflora Count. Journal of Animal and Poultry Production, 9(12): 453458.

Ministry of Agriculture (MOA) (2014). The state report of the agricultural sector in Jordan. Amman, Jordan.
Mohsen, MK, Abdel-Raouf, EM, Gaafar, HMA, Yousif, AM (2015). Nutritional evaluation of sprouted barley grains on agricultural by-products on performance of growing new zealand white rabbits. Nature and Science, 13(10): 35-45.

Mooney J (2005). Growing cattle feed hydroponically. Meat and livestock Australia. 30 pp.

Morales, M, Fuente, B, Juárez, M, Ávila, E (2009). Short communication: Effect of substituting hydroponic green barley forage for a commercial feed on performance of growing rabbits. World Rabbit Science. 17(1):35-38. doi:10.4995/wrs.2009.668.

Morgan, J, Hunter, RR, O'Haire, R (1992). Limiting factors in hydroponic barley grass production. $8^{\text {th }}$ International Congress on Soilless culture, Hunter's Rest, South Africa.

Morsy, AT, Abul SF, Emam, MSA (2013). Localized hydroponic green foragetechnology as a climate change adaptation under Egyptian condition. J. Agri. and Bio. Sci., 9 (6): 341-350.

Nagadi, SA (2019). Replace the Sprout Barley Instead of the Concentrated Fodder Including Anaerobic Probiotic $\mathrm{ZAD}^{\circledR}$ for Growing Rabbits. International Journal of Engineering Research \& Technology 8 (10): 105114.

Naik, PK, Dhuri, RB, Karunakaran, M, Swain, BK, Singh, NP (2013). Hydroponics technology for green fodder production. Indian Dairyman, 3: $54-58$.

Naik, PK, Dhuri, RB, Singh, NP (2011). Technology for production and feeding 
of hydroponics green fodder. Extension Folder No. 45/ 2011, ICAR Research Complex for Goa, Goa.

Naik, PK, Dhuri, RB, Swain, BK, Singh, NP (2012). Nutrient changes with the growth of hydroponics fodder maize. Indian J. Anim. Nutr. 29: 161-163.

Saidi, A, Abo Omar, J (2015). Economical and biological fasibility of hydroponic barley fed to lactating Awassi ewes. Open Journal of Animal Science, 5(2): 1-6.

Santoma, G, De Blas, JC, Carabano, R, Fraga, MJ (1989). Nutrition of rabbits. In: Recent Advances in Animal Nutrition. Haresing W., Cole D.J.A. (Eds). Buttherworths. UK, 109-138.
Sekken, MSMA, Taie, HT, Rabie, SA (2012). Utilization of sprouted fenugreek and/or sprouted barley in rabbit feeding. Egyptian Journal of Nutrition and Feeds, 15(2): 311-321.

Shanti, H, Omar, J, Alwaheidi, IN, Abdallah, J, Dbadran, E (2017). Effect of substituting hydroponic barley for a commercial feed on performance and blood metabolites of growing Baladi rabbits. New Science, 39(5): 21312135 .

Sneath, R and McIntosh, F (2003). Review of hydroponic fodder production for beef cattle. Department of Primary Industries: Queensland Australia 84. McKeehen, pp: 54. 